\title{
Neural Structures Mediating Expression and Extinction of Platform-Mediated Avoidance
}

\author{
Christian Bravo-Rivera, Ciorana Roman-Ortiz, Edith Brignoni-Perez, Francisco Sotres-Bayon, and Gregory J. Quirk \\ Departments of Psychiatry and Anatomy \& Neurobiology, University of Puerto Rico School of Medicine, San Juan, Puerto Rico 00936-5067
}

Individuals use both passive and active defensive responses to environmental threats. Much is known about the neural circuits of passive defensive responses (e.g., freezing), but less is known about the substrates of active defensive responses (e.g., avoidance). We developed an active avoidance task in which rats learn to avoid a tone-signaled footshock by stepping onto a nearby platform. An advantage of this task is that freezing, which can interfere with avoidance, is reduced, thereby facilitating comparison of the effects of manipulations on avoidance versus freezing. After $10 \mathrm{~d}$ of avoidance training, rats were infused with muscimol to pharmacologically inactivate the prelimbic cortex (PL), infralimbic cortex (IL), ventral striatum (VS), or basolateral amygdala (BLA). Inactivating PL, VS, or BLA all impaired avoidance expression, but these areas differed with respect to freezing. Inactivating BLA decreased freezing consistent with loss of the toneshock association, whereas inactivation of VS increased freezing consistent with loss of avoidance memory. Inactivation of PL had no effect on freezing. Inactivation of IL did not impair avoidance expression but did impair avoidance extinction. Our findings suggest that active avoidance is mediated by prefrontal-striatal circuits, which may be overactive in individuals suffering from trauma-related disorders.

Key words: amygdala; fear; infralimbic; prefrontal; prelimbic; striatum

\section{Introduction}

To ensure survival, individuals must express both passive and active defensive responses to environmental threats (Darwin, 1872; LeDoux, 2012). Passive responses such as freezing are reflexive (Blanchard and Blanchard, 1969), whereas active responses involve deciding to execute a specific action to avoid a threat (Mowrer and Lamoreaux, 1946). The neural circuits underlying freezing have been studied extensively in rodents using auditory fear conditioning. In this type of conditioning, tone and shock inputs converge and the association is stored in the basolateral nucleus of the amygdala (BLA; Fanselow and LeDoux, 1999; LeDoux, 2000; Blair et al., 2001; Maren and Quirk, 2004; Pelletier et al., 2005). BLA drives conditioned freezing through its projections to the central nucleus of the amygdala (LeDoux et al., 1988; Muller et al., 1997). Expression of amygdala-dependent fear memories is regulated by prelimbic (PL) and infralimbic (IL) prefrontal cortices, which increase and decrease freezing, respectively, through projections to the amygdala (Vidal-Gonzalez et

\footnotetext{
Received Jan. 15, 2014; revised June 1, 2014; accepted June 5, 2014.

Author contributions: C.B.-R., F.S.-B., and G.J.Q. designed research; C.B.-R., C.R.-O., and E.B.-P. performed research; C.B.-R., C.R.-O., E.B.-P., F.S.-B., and G.J.Q. analyzed data; C.B.-R. and G.J.Q. wrote the paper.

This work was supported by an American Psychology Association Diversity Program in Neuroscience fellowship and Grant MH102968 to C.B.-R., by Grants MH058883 and MH086400 to G.J.Q., and by the University of Puerto Rico President's Office. We thank E. Martinez-Maria, H. D. Bravo-Rivera, and M. Montesinos-Cartagena for surgical and experimental assistance. We also thank J. M. Moscarello and J.E. LeDoux for helpful comments on this manuscript. The authors declare no competing financial interests.

Correspondence should be addressed to Dr. Gregory J. Quirk, Department of Psychiatry, University of Puerto Rico School of Medicine, P.0. Box 365067, San Juan, Puerto Rico 00936-5067. E-mail: gregoryjquirk@gmail.com.

F. Sotres-Bayon's present address: Instituto de Fisiología Celular-Neurociencias, Universidad Nacional Autónoma de México, 04510 México D.F., México.

DOI:10.1523/JNEUROSCI.0191-14.2014

Copyright $\odot 2014$ the authors $\quad 0270-6474 / 14 / 349736-07 \$ 15.00 / 0$
}

al., 2006; Sotres-Bayon and Quirk, 2010; Amir et al., 2011; Cho et al., 2013).

Much less is known about neural circuits mediating active avoidance. As with fear responses, avoidance is excessive in individuals suffering from trauma-related disorders such as post-traumatic stress disorder (PTSD; American Psychiatric Association, 2013), emphasizing the need for understanding the substrates of avoidance. Active avoidance has been most studied using shuttle avoidance tasks, in which rats alternate between adjacent compartments to prevent the occurrence of a tone-signaled shock (Lubar, 1964; Theios and Dunaway, 1964; Wahlsten and Sharp, 1969; Vazdarjanova et al., 2001; Choi et al., 2010; Moscarello and LeDoux, 2013). Because shocks occur in both compartments, there is no "safe" place in the shuttle task: rats must enter a compartment in which they were previously shocked (Lubar, 1964). This positional conflict generates freezing that can oppose shuttling (Theios and Dunaway, 1964; Theios et al., 1966; Savonenko et al., 1999b; Lázaro-Muñoz et al., 2010; Moscarello and LeDoux, 2013). Recent lesion/inactivation studies have implicated the BLA (Choi et al., 2010; Lázaro-Muñoz et al., 2010), striatum (Darvas et al., 2011), and IL in shuttle avoidance (Moscarello and LeDoux, 2013). However, the use of this task makes it difficult to distinguish the effects of lesions on avoidance circuits from effects on freezing circuits.

We, therefore, developed an active avoidance task in which rats can avoid a signaled footshock by stepping onto a nearby platform that was never associated with shock, thereby eliminating the positional conflict of shuttle avoidance. Freezing levels are further reduced by bar pressing for sucrose pellets. We pharmacologically inactivated four structures [PL, IL, BLA, or ventral striatum (VS)] and measured tone-induced avoidance as well as tone-induced freezing and suppression of bar pressing. Our goal was to distinguish structures mediating avoidance from those 
mediating passive fear responses by comparing the effects of inactivation across behaviors.

\section{Materials and Methods}

Bar-press training. A total of 156 male Sprague Dawley rats (Harlan Laboratories) weighing 300-360 g were housed and handled as described previously (Quirk et al., 2000). Rats were restricted to $18 \mathrm{~g} / \mathrm{d}$ standard laboratory rat biscuits, followed by $7 \mathrm{~d}$ of training to press a bar for sucrose pellets on a variable interval schedule of reinforcement averaging $30 \mathrm{~s}$ (VI-30 s). Rats were trained until they reached a criterion of 10 presses per minute. All procedures were approved by the Institutional Animal Care and Use Committee of the University of Puerto Rico School of Medicine, in compliance with the National Institutes of Health Guide for the Care and Use of Laboratory Animals (eighth edition).

Cannula implantation. After bar-press training, rats were anesthetized with isofluorane inhalant gas $(5 \%)$ in an induction chamber and positioned in a stereotaxic frame. Isofluorane (2-3\%) was delivered through a face mask for anesthesia maintenance. Rats were implanted bilaterally with 26 gauge guide cannulas (Plastics One) targeting PL (AP, $+3.0 \mathrm{~mm}$; $\mathrm{ML}, \pm 0.60 \mathrm{~mm}$; DV,$-2.5 \mathrm{~mm}$ ), IL (AP, $2.8 \mathrm{~mm}$; ML, $\pm 0.60 \mathrm{~mm}$; DV, $-4.2 \mathrm{~mm}$ ), BLA (AP, $-2.8 \mathrm{~mm}$; ML, $\pm 5.0 \mathrm{~mm}$; DV, $-7.6 \mathrm{~mm}$ ), or VS (AP, $+2.0 \mathrm{~mm}$; ML, $\pm 2.0 \mathrm{~mm}$; DV,$-6.4 \mathrm{~mm}$; Paxinos and Watson 1998). For IL, an angled placement $\left(30^{\circ}\right)$ was used to avoid backflow into PL (Sierra-Mercado et al., 2011). Cannulas were fixed to the skull with dental cement and three stainless steel screws. After surgery, a triple antibiotic (Neosporin) was applied around the wound margin, and an NSAID analgesic (Ketofen; $2 \mathrm{mg} / \mathrm{kg}$ ) was injected intramuscularly. Stainless steel obturators (33 gauge) were inserted into the guide cannulas to prevent cannula blockage until infusions were made. After surgery, animals were allowed to recover for $7 \mathrm{~d}$ before the experiments.

Drug infusions. Rats were infused as described previously (SierraMercado et al., 2011). The day before infusions, injectors were briefly inserted into the cannulas without infusing, and rats were acclimated for infusion handling. Injector tips extended $1.0 \mathrm{~mm}$ beyond the guide cannula. Muscimol (MUS; Sigma-Aldrich) was used to enhance $\mathrm{GABA}_{\mathrm{A}}$ receptor activity, thereby inactivating target structures, and was infused 45 min before behavioral testing. MUS or saline vehicle (SAL) was infused at a rate of $0.2 \mu \mathrm{l} / \mathrm{min}$ for PL or IL $(0.11 \mathrm{nmol} / 0.2 \mu \mathrm{l}$ per side $)$ and $0.25 \mu \mathrm{l} / \mathrm{min}$ for BLA $(0.11 \mathrm{nmol} / 0.5 \mu \mathrm{l}$ per side $)$ and VS $(0.11 \mathrm{nmol} / 0.3$ $\mu l$ per side). Dosages of MUS were selected to match our previous study of PL, IL, and BLA in fear conditioning (Sierra-Mercado et al., 2011), in which these dosages did not affect locomotion. After infusion, injectors were left in place for $1 \mathrm{~min}$ to allow the drug to diffuse.

Platform-mediated avoidance training. Rats were conditioned and tested in standard operant chambers $(26.7 \mathrm{~cm}$ long, $27.9 \mathrm{~cm}$ wide, 27.9 $\mathrm{cm}$ tall; Coulbourn Instruments) located in sound-attenuating cubicles (MED Associates). The floor of the chambers consisted of stainless steel bars delivering a scrambled electric footshock. Between experiments, shock grids and floor trays were cleaned with soap and water, and chamber walls were cleaned with wet paper towels. Sucrose pellets were available on a VI-30 s schedule throughout all phases of training, testing, and extinction. Availability of reward motivated rats to leave the platform during the intertrial interval, enabling trial-by-trial assessment of avoidance. Rats were conditioned with a pure tone $(30 \mathrm{~s}, 4 \mathrm{kHz}, 75 \mathrm{~dB})$ coterminating with a shock delivered through the floor grids $(2 \mathrm{~s}, 0.4 \mathrm{~mA})$. The intertrial interval was variable, averaging $3 \mathrm{~min}$. Compared with our fear conditioning task, we used a longer shock duration ( $2 \mathrm{~s}$ vs $0.5 \mathrm{~s})$ to mobilize rats onto the platform and a slightly lower shock intensity $(0.4$ $\mathrm{mA}$ vs $0.5 \mathrm{~mA}$ ) to prevent overconditioning. An acrylic square platform $(14.0 \mathrm{~cm}$ each side, $0.33 \mathrm{~cm}$ tall) located in the opposite corner of the sucrose-delivering bar protected rats from the shock. The platform was fixed to the floor and was present in all stages of training (including bar-press training) to reduce novelty.

Rats were conditioned for $10 \mathrm{~d}$ to reduce tone-induced freezing and allow spontaneous press rates to return to preconditioning levels. Each day, rats received three sessions consisting of three tone-shock trials each (nine tone-shock pairings per day). Rats were left in the training chamber between sessions for $5 \mathrm{~min}$ to reinforce bar-press training and to reduce contextual fear. Rats failing to avoid during the first two trials of

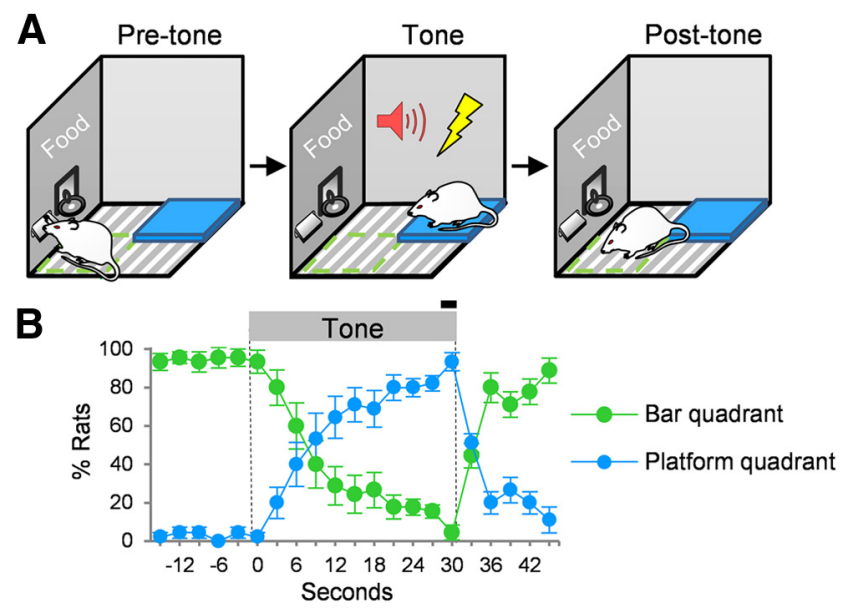

Figure 1. Expression of platform-mediated avoidance. $A$, Rats press a bar for sucrose pellets (green quadrant). At tone onset, they gradually step onto the platform to avoid shock (blue quadrant). At tone offset, they gradually return to the bar. $\boldsymbol{B}$, The position of the rat was defined as the quadrant in which both front paws were located and was scored every $3 \mathrm{~s}$ from videos by a trained observer. Position data were scored for days 9 and 10 of conditioning (Trials $1-3, n=12$ rats). The black bar indicates shock. In this and subsequent figures, error bars depict SEM.

day 10 of conditioning were excluded from the experiment (5 of 156 rats). On day 11, rats were infused with either muscimol or saline and presented with a two-tone test with the shocker off. For the avoidance extinction experiment, rats were presented daily with 15 tones without shocks in the same conditioning chamber with the platform present. After two extinction training days, rats were presented with an extinction test (two tones) the following day.

Histology. After completion of experiments, rats were transcardially perfused with $0.9 \%$ saline followed by $10 \%$ buffered formalin. Brains were extracted and stored in a $30 \%$ sucrose $/ 10 \%$ formalin solution for $3 \mathrm{~d}$. Coronal sections were cut ( $40 \mu \mathrm{m}$ thick) on a cryostat, mounted on slides, and stained for Nissl bodies for cannula placement histology. Because of misplacement of cannulas on one or both sides of the brain, 20 of 151 rats were excluded from this study, leaving a total of 131 rats.

Data analysis. Behavior was recorded with digital video cameras (Micro Video Products), and freezing was detected using software (Freezescan; Clever Systems). Trials of experimental groups (SAL and MUS) were compared with unpaired Student's two-tailed $t$ tests for avoidance expression experiments or repeated-measures ANOVA, followed by Tukey's post hoc comparisons (STATISTICA; StatSoft) for the avoidance extinction experiment. The amount of time freezing to the tone was expressed as a percentage of the tone duration. We also measured time spent freezing $1 \mathrm{~min}$ before tone onset (pretone freezing). Successful avoidance was defined as the rat having at least two paws on the platform between seconds 28 and 30 of the tone (shock period). Avoidance was scored from video recordings of the sessions by a trained observer. We also measured time spent on the platform $1 \mathrm{~min}$ before tone onset (pretone avoidance) as well as during the tone. We measured percent suppression of bar pressing to the tone (Quirk et al., 2000), calculated as follows: (pretone rate - tone rate) $/($ pretone rate + tone rate $) \times(100)$. A value of 0 indicates no suppression, whereas a value of 100 indicates complete suppression.

\section{Results}

\section{Acquisition of platform-mediated avoidance}

For conditioning of platform-mediated avoidance, rats were presented with nine tone-shock trials per day. Because the platform was located far from the sucrose-delivering bar, mounting prevented rats from bar pressing, thereby constituting a "cost" of avoidance. We used a cohort of unimplanted rats to characterize several behaviors across acquisition of avoidance training. After $10 \mathrm{~d}$ of conditioning, rats learned to step onto the platform at the 


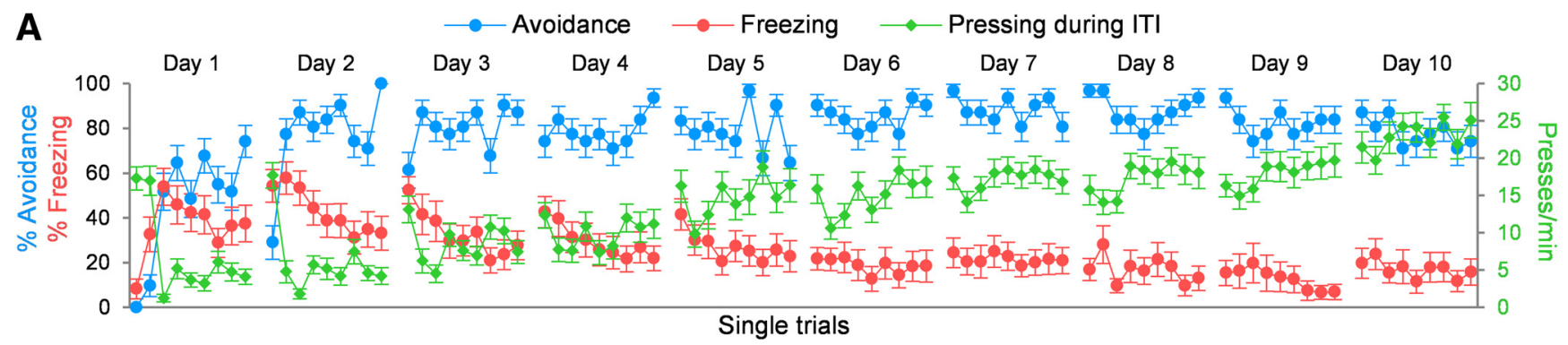

B

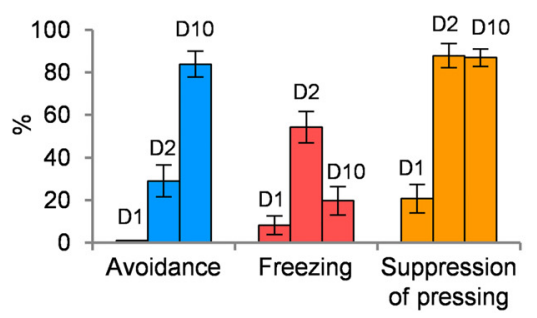

Figure 2. Acquisition of platform-mediated avoidance. $\boldsymbol{A}$, Rats were trained for $10 \mathrm{~d}$, receiving nine avoidance trials per day. As rats learn to avoid, freezing to the tone gradually decreases, and bar pressing during the intertrial interval (ITI) returns to preconditioning levels. Data shown are from unimplanted rats ( $n=31)$. \% Avoidance refers to the percentage of rats that successfully avoided in a given trial. \% Freezing refers to the percentage of 30 s tone spent freezing in each trial. B, Behavioral data are shown for the first trial of day 1 (D1), day 2 (D2), and day 10 (D10). On day 2 , rats showed little avoidance, but high levels of freezing and suppression of bar pressing. By day 10 , rats showed high avoidance, low freezing, and high suppression.

start of the tone, returning to the bar at the end of the tone $(30 \mathrm{~s}$; Fig. 1). After the first day of conditioning, freezing and suppression increased, intertrial interval pressing decreased, but avoidance was still minimal. With additional days of training, avoidance increased, freezing decreased, and ITI pressing returned to preconditioning levels (Fig. 2). This is consistent with earlier (Mowrer and Lamoreaux, 1946; Miller, 1948; Mowrer, 1960) as well as more recent (Choi et al., 2010; Lázaro-Muñoz et al., 2010; Martinez et al., 2013; Moscarello and LeDoux, 2013) studies showing that acquisition of avoidance reduces freezing, reflecting the adaptive nature of avoidance. We next used pharmacological inactivation to determine the structures mediating expression of platform-mediated avoidance.

\section{Inactivation of prelimbic cortex blocks avoidance}

In our auditory fear-conditioning task, in which rats also bar press for sucrose, inactivation of PL impairs both conditioned freezing and tone-induced suppression of bar pressing (Corcoran and Quirk, 2007; Sierra-Mercado et al., 2011). Moreover, PL neurons exhibit sustained tone responses correlating with freezing across the 30 s tone (Burgos-Robles et al., 2009; Sotres-Bayon et al., 2012). Inactivation of IL in fear conditioning does not block expression of conditioned freezing but impairs its extinction (Laurent and Westbrook, 2009b; Sierra-Mercado et al., 2011). Given that PL and IL are capable of modulating tone-triggered freezing (Sotres-Bayon and Quirk, 2010), we reasoned that these structures might also modulate tone-triggered avoidance. We, therefore, inactivated either PL or IL after $10 \mathrm{~d}$ of conditioning (on day 11), using the same dose of muscimol that we used previously (Sierra-Mercado et al., 2011). There was little contextual fear across all experiments (SAL and MUS groups), as evidenced by low levels of pretone freezing (all group averages $<13.4 \%$ ) and low levels of pretone time on platform (all group averages $<13.9 \%$ ).

As shown in Figure $3 A$, inactivation of PL reduced avoidance (SAL, 85.7\%; MUS, 26.7\%; $t_{(34)}=3.73 ; p<0.001$ ) but did not reduce freezing (SAL, 60.0\%; MUS, 68.4\%; $t_{(34)}=0.69 ; p=0.49$ ), spontaneous bar pressing (SAL, 17.8 presses/min; MUS, 18.6 presses $\left./ \mathrm{min} ; t_{(34)}=0.25 ; p=0.80\right)$, or suppression of bar pressing (SAL, $83.9 \%$; MUS, $90.0 \%$; $\left.t_{(34)}=0.62 ; p=0.54\right)$. PL inactivation also reduced time on platform during the tone (SAL, $65.7 \%$; MUS, $\left.29.6 \% ; t_{(34)}=2.54 ; p=0.016\right)$. This contrasts with auditory fear conditioning, in which PL inactivation reduced both freezing and suppression of bar pressing (Sierra-Mercado et al., 2011). In contrast to PL, as shown in Figure $3 B$, inactivation of IL had no effect on avoidance (SAL, $81.3 \%$; MUS, $80.0 \%$; $t_{(26)}=$ $0.08 ; p=0.94$ ) or time on platform during tone (SAL, 96.7\%; MUS, $\left.61.0 \% ; t_{(26)}=0.70 ; p=0.49\right)$. Furthermore, passive fear was increased, as indicated by freezing (SAL, 27.3\%; MUS, $49.5 \%$; $t_{(26)}=2.30 ; p=0.030$ ), suppression of bar pressing (SAL, 88.0\%; MUS, $\left.99.1 \% ; t_{(26)}=2.15 ; p=0.048\right)$, and spontaneous press rates (SAL, 22.7 presses/min; MUS, 13.1 presses/min; $t_{(26)}=2.68$; $p=0.017)$. This increase in passive fear suggests that IL reduces freezing during avoidance as previously shown (Moscarello and LeDoux, 2013), but is not necessary for expression of platformmediated avoidance.

Inactivation of VS blocks avoidance and increases passive fear PL projects robustly to VS (Sesack et al., 1989; Gabbott et al., 2005), an area implicated in locomotor control (Kelly and Moore, 1976) and shuttle avoidance (Darvas et al., 2011). A recent study reported delayed acquisition of avoidance after pretraining VS lesions (Wendler et al., 2014), but no prior study examined the role of VS in the expression of previously acquired avoidance.

We, therefore, tested whether VS was critical for platformmediated avoidance by inactivating the VS region receiving the most input from PL (covering both the core and shell of accumbens; Sesack et al., 1989). Similar to PL, inactivation of VS impaired avoidance (SAL, 88.9\%; MUS, $16.4 \%$; $t_{(19)}=3.18 ; p=$ $0.005)$, as shown in Figure $3 C$. Additionally, VS inactivation also decreased time on platform during tone (SAL, 76.3\%; MUS, $\left.4.2 \% ; t_{(19)}=8.10 ; p<0.001\right)$. Inactivation of VS also increased freezing (SAL, 37.0\%; MUS, 68.3\%; $t_{(19)}=2.16 ; p=0.043$ ) but had no effect on suppression of bar pressing (SAL, 89.9\%; MUS, 

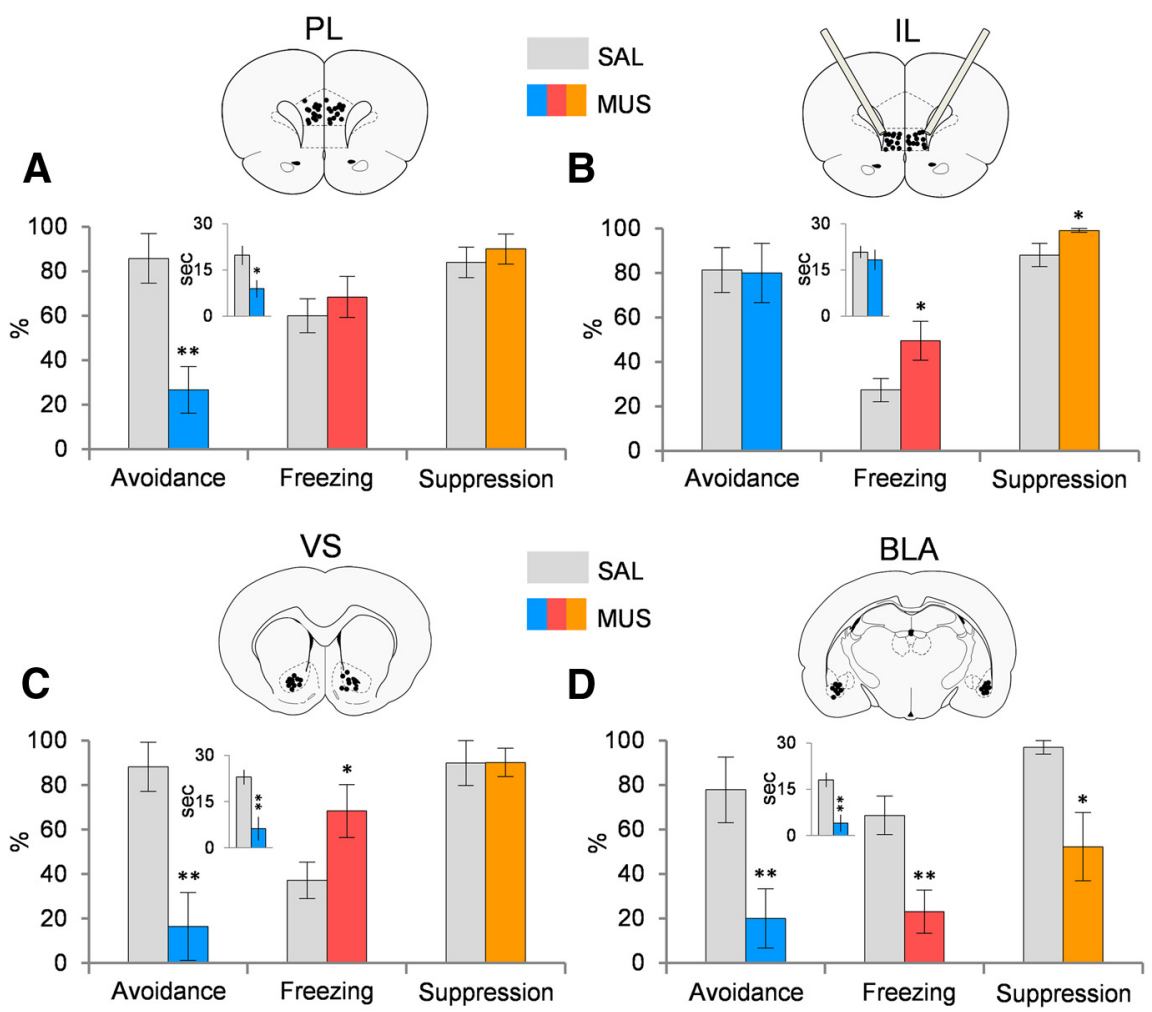

Figure 3. Effects of inactivation of PL, IL, VS, or BLA on avoidance and passive fear responses. $\boldsymbol{A}$, Inactivation of PL with muscimol impaired avoidance but did not alter freezing or suppression (MUS, $n=17 ; S A L, n=18$ ). $\boldsymbol{B}$, Inactivation of IL did not impair avoidance but increased freezing and suppression (MUS, $n=13 ; \mathrm{SAL}, n=16$ ). $\boldsymbol{C}$, Inactivation of VS impaired avoidance and increased freezing (MUS, $n=8$; SAL, $n=12$ ). $\boldsymbol{D}$, Inactivation of BLA impaired avoidance and decreased both freezing and suppression, consistent with loss of the tone-shock association (MUS, $n=8 ; S A L, n=10$ ). Data are presented for the first trial of Day 11. ${ }^{*} p<0.05 ;{ }^{* *} p<0.01$, Student's $t$ test (unpaired, two-tailed). The inset graphs indicate the time (in seconds) spent on the platform during the tone. Atlas figures indicate placements of injector tips.

$\left.90.1 \% ; t_{(19)}=1.07 ; p=0.30\right)$ or on spontaneous pressing $(\mathrm{SAL}$, 12.6 presses $/ \mathrm{min}$; MUS, 10.3 presses $\left./ \mathrm{min} ; t_{(19)}=0.72 ; p=0.48\right)$. Thus, both VS and PL are necessary for avoidance. To address possible effects on locomotion, we performed an open field test. We corroborated that inactivation of VS does not alter locomotion $\left(t_{(12)}=0.97 ; p=0.35\right.$ ) similar to a previous study (Atallah et al., 2007). Additionally, to test for a possible interaction between freezing and avoidance, we performed a regression analysis comparing freezing with time on platform across all four experiments $(n=97)$ and found no significant correlation $\left(r=0.12 ; F_{(1,96)}=\right.$ $1.51 ; p=0.22$ ), suggesting that freezing does not compete with avoidance in this task.

Inactivation of BLA blocks both avoidance and passive fear Another PL target is the BLA (Chiba et al., 2001; Vertes, 2004; Gabbott et al., 2005), which is necessary for acquisition, expression, and extinction of conditioned fear (LeDoux, 2000; AngladaFigueroa and Quirk, 2005; Blair et al., 2005; Davis, 2006; Ponnusamy et al., 2007; Laurent and Westbrook, 2009a; SotresBayon et al., 2012). Lesions or inactivation of BLA impair expression of shuttle avoidance (Choi et al., 2010) as well as "escape from fear" (Amorapanth et al., 2000). In agreement with these findings, we found that inactivation of BLA virtually eliminated expression of platform-mediated avoidance (SAL, 80.0; MUS, $18.8 \% ; t_{(17)}=3.29 ; p=0.0045$; Fig. $\left.3 D\right)$ and reduced time on platform during the tone (SAL, 76.3; MUS, $20.7 \%$; $t_{(17)}=3.58$; $p=0.002$ ). However, in contrast to PL, IL, and VS, inactivation of BLA significantly reduced both freezing (SAL, 66.3\%; MUS, $\left.23.0 \% ; t_{(17)}=3.30 ; p=0.004\right)$ and barpress suppression (SAL, 96.9\%; MUS, $52.2 \% ; t_{(17)}=2.19 ; p=0.043$; Fig. $\left.3 D\right)$ but had no effect on spontaneous pressing (SAL, 16.3 presses/min; MUS, 20.0 press$\left.\mathrm{es} / \mathrm{min} ; t_{(17)}=0.66 ; p=0.51\right)$. The reduction in passive fear to the tone (freezing and suppression) is consistent with the role of BLA in storage of the tone-shock association (Quirk et al., 1995; LeDoux, 2000; Blair et al., 2001).

\section{Inactivation of IL impairs extinction of avoidance}

Previous studies have linked IL to fear extinction (Mueller et al., 2010; Peters et al., 2010; Santini and Porter, 2010; Thompson et al., 2010; Fontanez-Nuin et al., 2011; Holmes et al., 2012), proposing that IL inhibits freezing via feed-forward inhibition of the amygdala (Quirk et al., 2003; Amano et al., 2010; Amir et al., 2011). In particular, inactivating IL immediately before fear extinction training leaves extinction intact but impairs retrieval of extinction the next day (Laurent and Westbrook, 2009b; Sierra-Mercado et al., 2011; Holmes et al., 2012). We, therefore, hypothesized that IL may also be important for extinction of avoidance.

Inactivation of IL had no effect on within-session extinction of avoidance on day 11 (Fig. 4). ANOVA on this day revealed no effect of group $\left(F_{(1,28)}=0.84\right.$; $p=0.37)$ or interaction of group with trial block $\left(F_{(6,150)}=0.85 ; p=0.53\right)$. The following day (day 12$)$, retrieval of avoidance extinction was impaired (group: $F_{(1,28)}=7.97$, $p=0.009$; trial block: $F_{(6,150)}=30.40, p<0.001$; interaction: $\left.F_{(6,150)}=7.39, p<0.001\right)$. Post hoc comparisons confirmed that MUS-infused rats avoided more than controls in trial blocks 1 and $2(p<0.05)$, and showed elevated suppression in block 1 $(p=0.030)$. Surprisingly, MUS-infused rats continued to show impaired retrieval of avoidance extinction $1 \mathrm{~d}$ later (day 13; SAL, $25.0 \%$; MUS, $86.4 \%$; $t_{(28)}=3.90 ; p<0.001$ ) despite receiving extinction drug free the previous day. Inactivation of IL also reduced spontaneous bar pressing on day 11 (SAL, 22.7 presses/ min; MUS, 13.1 presses $\left./ \mathrm{min} ; t_{(28)}=2.68 ; p=0.017\right)$ and increased tone-induced suppression on day 12 (SAL, 29.4\%; MUS, $\left.74.9 \% ; t_{(28)}=4.22 ; p<0.001\right)$. Freezing was elevated only during the first block of extinction on day 11 (SAL, 23.2\%; MUS, $\left.56.7 \% ; t_{(28)}=4.07 ; p<0.001\right)$, but not during subsequent drugfree days. Thus, inactivating IL during the first day of extinction prevented rats from subsequently learning extinction.

\section{Discussion}

We developed a signaled active avoidance task that facilitates comparison of passive fear responses (freezing and suppression) with avoidance responses. Pharmacological inactivation of PL, VS, or BLA all blocked avoidance. Unlike inactivation of PL and VS, inactivation of BLA decreased passive fear responses. Inactivation of IL left avoidance intact but impaired subsequent extinction of avoidance. 


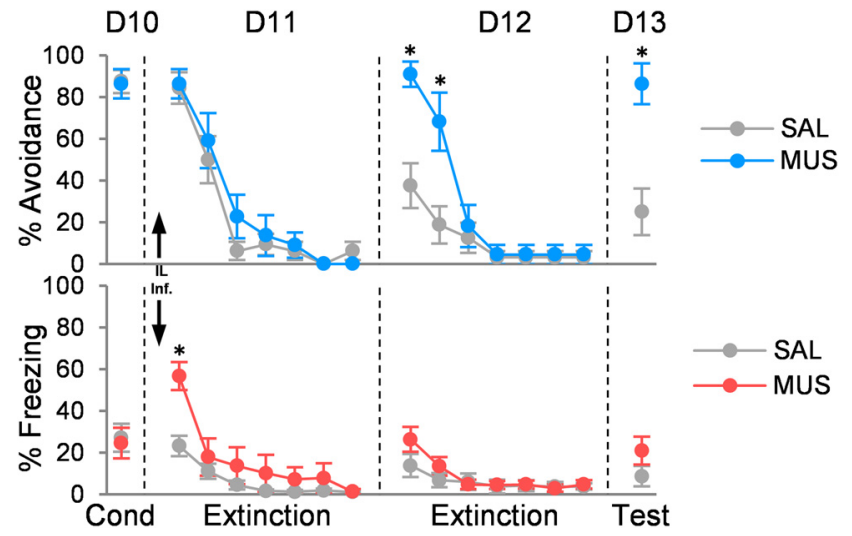

Figure 4. Inactivation of infralimbic cortex impairs extinction of platform-mediated avoidance. Inactivating IL with muscimol had no effect on within-session extinction of avoidance (D11), but impaired retrieval of extinction on day 12 (D12) and day 13 (D13; both drug free). Increased avoidance on these days was not accompanied by an increase in freezing. Data are shown in blocks of two trials (MUS, $n=11 ; S A L, n=16$ ). Arrows indicates infusion. ${ }^{*} p<0.05$, Tukey's post hoc test.

\section{Ventral striatum is necessary for platform-mediated avoidance} VS represents a limbic-motor interface (Mogenson et al., 1980) and is critical for instrumental conditioning (Cardinal et al., 2002); however, there are few studies directly assessing its role in active avoidance. Acquisition of shuttle avoidance was impaired by pretraining lesions of the VS (Wendler et al., 2014). Additionally, restoring dopamine in the striatum of dopamine-depleted mice rescued shuttle avoidance learning (Darvas et al., 2011). Rather than acquisition of avoidance, we focused on expression of previously learned avoidance. Inactivation of VS blocked the expression of platform-mediated avoidance but also increased passive fear to the tone, indicating that rats maintained the toneshock association in the absence of avoidance memory.

\section{BLA signals the tone-shock association in platform-mediated avoidance}

In auditory fear conditioning, there is extensive evidence that the BLA stores the tone-shock association (Fanselow and LeDoux, 1999; LeDoux, 2000; Blair et al., 2001; Maren and Quirk, 2004; Pelletier et al., 2005; Davis, 2006). This is consistent with our observation that both avoidance and fear responses to the tone were lost after BLA inactivation. Thus, rats would not be expected to express either passive fear or avoidance to tones no longer associated with shocks. This is consistent with reduced expression of tone-signaled shuttle avoidance after lesions of the basal or lateral nuclei of the amygdala (Choi et al., 2010), as well as the lack of effect of amygdala lesions on expression of Sidman shuttle avoidance, in which there is no tone (Lázaro-Muñoz et al., 2010).

\section{Prelimbic cortex is necessary for platform-mediated avoidance}

We found that inactivation of PL impaired avoidance expression but had no effect on freezing or suppression. Previous studies have not examined the effect of post-training lesions or inactivation of PL on the expression of active avoidance. Pretraining lesions of PL were shown to have no effect on shuttle avoidance (Moscarello and LeDoux, 2013), suggesting the possibility of post-lesion recovery of function. The lack of effect on freezing contrasts with our previous fear-conditioning studies, in which PL inactivation reduced both freezing and suppression of bar pressing to a conditioned tone (Sierra-Mercado et al., 2011). Platform-mediated avoidance requires many more days of train-
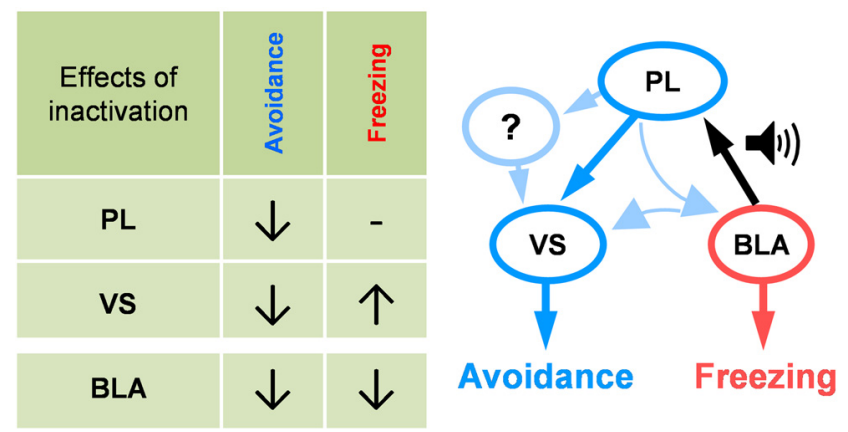

Figure 5. Possible circuits of platform-mediated avoidance. Left, Table summarizing inactivation data. Right, Circuit that could mediate avoidance and freezing to a conditioned tone. PL receives conditioned tone response from the BLA and could drive avoidance through direct or indirect projections to VS.

ing than fear conditioning ( $10 \mathrm{~d}$ vs $1 \mathrm{~d}$ ), which may recruit additional regions into the freezing circuit (Poulos et al., 2010; Zelikowsky et al., 2013). Unit recording data will be needed to further understand the role of PL in avoidance.

PL projects densely to the VS (Sesack et al., 1989; Vertes, 2004) and could drive avoidance through these projections (Fig. 5). Alternatively, PL could modulate VS indirectly through BLA (Sesack et al., 1989; Vertes, 2004), which then projects to the VS (Kita and Kitai, 1990; Stuber et al., 2011), or through other structures. Projections from BLA to VS have been previously proposed for active avoidance (Killcross et al., 1997; LeDoux and Gorman, 2001), but additional techniques (e.g., optogenetics) are needed to identify the specific circuits of active avoidance.

\section{Infralimbic cortex is necessary for avoidance extinction but not expression}

In contrast to PL, inactivation of IL did not impair platformmediated avoidance, even though it increased freezing and suppression. The increase in passive fear replicates a recent finding from a shuttle avoidance task, in which IL inactivation increased freezing; however, the expression of avoidance was also impaired in that study (Moscarello and LeDoux, 2013). Because freezing more readily competes with avoidance in the shuttle task (Savonenko et al., 1999a; Choi et al., 2010; Martinez et al., 2013), IL may mediate inhibition of freezing but may not mediate expression of avoidance. In platform-mediated avoidance, freezing is somewhat reduced because of a lower level of shock ( 0.4 vs 0.7 $\mathrm{mA}$ ) as well as the motivation to press for sucrose. Under these conditions, IL is not necessary for avoidance even though it inhibits freezing.

Importantly, we found that IL is necessary for forming a memory of extinction of avoidance, consistent with its role in extinction of fear conditioning (Burgos-Robles et al., 2007; Laurent and Westbrook, 2009b; Amir et al., 2011; Fontanez-Nuin et al., 2011; Sierra-Mercado et al., 2011). Previous studies have linked extinction of active avoidance with the amygdala (Jiao et al., 2011), medial septum (Pang et al., 2011), and anterior thalamus (Gabriel et al., 1983), but not to IL. This adds to a growing number of tasks for which IL is essential for extinction, including appetitive conditioning (Rhodes and Killcross, 2004; Rhodes and Killcross, 2007; Peters and De Vries, 2013), conditioned taste aversion (Mickley et al., 2005), and cocaine seeking (Peters et al., 2008). IL could mediate extinction of avoidance via projections to VS and/or to the amygdala. Interestingly, inactivation of IL impeded subsequent extinction learning, even under drug-free conditions. A similar finding has been reported for extinction of step-down inhibitory 
avoidance (Cammarota et al., 2005), suggesting the existence of a critical time window for the learning of avoidance extinction.

\section{Avoidance in anxiety disorders}

Excessive avoidance is now a required symptom for the diagnosis of PTSD (American Psychiatric Association, 2013). Emerging findings from human functional imaging studies implicate the PL-VS circuit in avoidance: (1) the dorsal anterior cingulate cortex (dACC), which is a functional homolog of PL (Milad et al., 2007), has been linked to avoidance of snakes (Nili et al., 2010) and shocks (Straube et al., 2009); and (2) VS has also been linked to avoidance of shocks (Delgado et al., 2009). PTSD patients show excessive activity in dACC as well as decreased activity in the ventromedial prefrontal cortex (vmPFC; a functional homolog of IL; Milad et al., 2009; Linnman et al., 2012). Excessive avoidance in PTSD, therefore, may reflect excessive activity in cingulate-striatal circuits mediating avoidance expression and/or deficient activity in vmPFC circuits mediating avoidance extinction.

\section{Notes}

Supplemental material for this article is available at http://media.md.rcm.upr. edu/Mediasite/Play/07ed951d40254bc5889a25ac71e945761d. It is a video example of platform-mediated avoidance. This material has not been peer reviewed.

\section{References}

Amano T, Unal CT, Paré D (2010) Synaptic correlates of fear extinction in the amygdala. Nat Neurosci 13:489-494. CrossRef Medline

American Psychiatric Association (2013) Diagnostic and statistical manual of mental disorders, Ed 5. Arlington, VA: American Psychiatric Publishing.

Amir A, Amano T, Pare D (2011) Physiological identification and infralimbic responsiveness of rat intercalated amygdala neurons. J Neurophysiol 105:3054-3066. CrossRef Medline

Amorapanth P, LeDoux JE, Nader K (2000) Different lateral amygdala outputs mediate reactions and actions elicited by a fear-arousing stimulus. Nat Neurosci 3:74-79. CrossRef Medline

Anglada-Figueroa D, Quirk GJ (2005) Lesions of the basal amygdala block expression of conditioned fear but not extinction. J Neurosci 25:96809685. CrossRef Medline

Atallah HE, Lopez-Paniagua D, Rudy JW, O’Reilly RC (2007) Separate neural substrates for skill learning and performance in the ventral and dorsal striatum. Nat Neurosci 10:126-131. CrossRef Medline

Blair HT, Schafe GE, Bauer EP, Rodrigues SM, LeDoux JE (2001) Synaptic plasticity in the lateral amygdala: a cellular hypothesis of fear conditioning. Learn Mem 8:229-242. CrossRef Medline

Blair HT, Sotres-Bayon F, Moita MA, Ledoux JE (2005) The lateral amygdala processes the value of conditioned and unconditioned aversive stimuli. Neuroscience 133:561-569. CrossRef Medline

Blanchard RJ, Blanchard DC (1969) Crouching as an index of fear. J Comp Physiol Psychol 67:370-375. CrossRef Medline

Burgos-Robles A, Vidal-Gonzalez I, Santini E, Quirk GJ (2007) Consolidation of fear extinction requires NMDA receptor-dependent bursting in the ventromedial prefrontal cortex. Neuron 53:871-880. CrossRef Medline

Burgos-Robles A, Vidal-Gonzalez I, Quirk GJ (2009) Sustained conditioned responses in prelimbic prefrontal neurons are correlated with fear expression and extinction failure. J Neurosci 29:8474-8482. CrossRef Medline

Cammarota M, Bevilaqua LR, Rossato JI, Ramirez M, Medina JH, Izquierdo I (2005) Relationship between short- and long-term memory and shortand long-term extinction. Neurobiol Learn Mem 84:25-32. CrossRef Medline

Cardinal RN, Parkinson JA, Hall J, Everitt BJ (2002) Emotion and motivation: the role of the amygdala, ventral striatum, and prefrontal cortex. Neurosci Biobehav Rev 26:321-352. CrossRef Medline

Chiba T, Kayahara T, Nakano K (2001) Efferent projections of infralimbic and prelimbic areas of the medial prefrontal cortex in the Japanese monkey, Macaca fuscata. Brain Res 888:83-101. CrossRef Medline

Cho JH, Deisseroth K, Bolshakov VY (2013) Synaptic encoding of fear ex- tinction in mPFC-amygdala circuits. Neuron 80:1491-1507. CrossRef Medline

Choi JS, Cain CK, LeDoux JE (2010) The role of amygdala nuclei in the expression of auditory signaled two-way active avoidance in rats. Learn Mem 17:139-147. CrossRef Medline

Corcoran KA, Quirk GJ (2007) Activity in prelimbic cortex is necessary for the expression of learned, but not innate, fears. J Neurosci 27:840-844. CrossRef Medline

Darvas M, Fadok JP, Palmiter RD (2011) Requirement of dopamine signaling in the amygdala and striatum for learning and maintenance of a conditioned avoidance response. Learn Mem 18:136-143. CrossRef Medline

Darwin C (1872) The expression of the emotions in man and animals. London: Fontana.

Davis M (2006) Neural systems involved in fear and anxiety measured with fear-potentiated startle. Am Psychol 61:741-756. CrossRef Medline

Delgado MR, Jou RL, Ledoux JE, Phelps EA (2009) Avoiding negative outcomes: tracking the mechanisms of avoidance learning in humans during fear conditioning. Front Behav Neurosci 3:33. CrossRef Medline

Fanselow MS, LeDoux JE (1999) Why we think plasticity underlying Pavlovian fear conditioning occurs in the basolateral amygdala. Neuron 23: 229-232. CrossRef Medline

Fontanez-Nuin DE, Santini E, Quirk GJ, Porter JT (2011) Memory for fear extinction requires mGluR5-mediated activation of infralimbic neurons. Cereb Cortex 21:727-735. CrossRef Medline

Gabbott PL, Warner TA, Jays PR, Salway P, Busby SJ (2005) Prefrontal cortex in the rat: projections to subcortical autonomic, motor, and limbic centers. J Comp Neurol 492:145-177. CrossRef Medline

Gabriel M, Lambert RW, Foster K, Orona E, Sparenborg S, Maiorca RR (1983) Anterior thalamic lesions and neuronal activity in the cingulate and retrosplenial cortices during discriminative avoidance behavior in rabbits. Behav Neurosci 97:675-696. CrossRef Medline

Holmes A, Fitzgerald PJ, MacPherson KP, DeBrouse L, Colacicco G, Flynn SM, Masneuf S, Pleil KE, Li C, Marcinkiewcz CA, Kash TL, Gunduz-Cinar O, Camp M (2012) Chronic alcohol remodels prefrontal neurons and disrupts NMDAR-mediated fear extinction encoding. Nat Neurosci 15: 1359-1361. CrossRef Medline

Jiao X, Pang KC, Beck KD, Minor TR, Servatius RJ (2011) Avoidance perseveration during extinction training in Wistar-Kyoto rats: an interaction of innate vulnerability and stressor intensity. Behav Brain Res 221:98107. CrossRef Medline

Kelly PH, Moore KE (1976) Mesolimbic dopaminergic neurones in the rotational model of nigrostriatal function. Nature 263:695-696. CrossRef Medline

Killcross S, Robbins TW, Everitt BJ (1997) Different types of fearconditioned behaviour mediated by separate nuclei within amygdala. Nature 388:377-380. CrossRef Medline

Kita H, Kitai ST (1990) Amygdaloid projections to the frontal cortex and the striatum in the rat. J Comp Neurol 298:40-49. CrossRef Medline

Laurent V, Westbrook RF (2009a) Infusion of the NMDA receptor antagonist, DL-APV, into the basolateral amygdala disrupts learning to fear a novel and a familiar context as well as relearning to fear an extinguished context. Learn Mem 16:96-105. CrossRef Medline

Laurent V, Westbrook RF (2009b) Inactivation of the infralimbic but not the prelimbic cortex impairs consolidation and retrieval of fear extinction. Learn Mem 16:520-529. CrossRef Medline

Lázaro-Muñoz G, LeDoux JE, Cain CK (2010) Sidman instrumental avoidance initially depends on lateral and basal amygdala and is constrained by central amygdala-mediated Pavlovian processes. Biol Psychiatry 67: 1120-1127. CrossRef Medline

LeDoux JE (2000) Emotion circuits in the brain. Annu Rev Neurosci 23: 155-184. CrossRef Medline

LeDoux JE (2012) Evolution of human emotion: a view through fear. Prog Brain Res 195:431-442. CrossRef Medline

LeDoux JE, Gorman JM (2001) A call to action: overcoming anxiety through active coping. Am J Psychiatry 158:1953-1955. CrossRef Medline

LeDoux JE, Iwata J, Cicchetti P, Reis DJ (1988) Different projections of the central amygdaloid nucleus mediate autonomic and behavioral correlates of conditioned fear. J Neurosci 8:2517-2529. Medline

Linnman C, Zeidan MA, Pitman RK, Milad MR (2012) Resting cerebral metabolism correlates with skin conductance and functional brain acti- 
vation during fear conditioning. Biol Psychol 89:450-459. CrossRef Medline

Lubar JF (1964) Effect of medial cortical lesions on the avoidance behavior of the cat. J Comp Physiol Psychol 58:38-46. CrossRef Medline

Maren S, Quirk GJ (2004) Neuronal signalling of fear memory. Nat Rev Neurosci 5:844-852. CrossRef Medline

Martinez RC, Gupta N, Lázaro-Muñoz G, Sears RM, Kim S, Moscarello JM, LeDoux JE, Cain CK (2013) Active vs. reactive threat responding is associated with differential c-Fos expression in specific regions of amygdala and prefrontal cortex. Learn Mem 20:446-452. CrossRef Medline

Mickley GA, Kenmuir CL, Yocom AM, Wellman JA, Biada JM (2005) A role for prefrontal cortex in the extinction of a conditioned taste aversion. Brain Res 1051:176-182. CrossRef Medline

Milad MR, Quirk GJ, Pitman RK, Orr SP, Fischl B, Rauch SL (2007) A role of the human dorsal anterior cingulate cortex in expression of learned fear. Biol Psychiatry 62:1191-1194. CrossRef Medline

Milad MR, Pitman RK, Ellis CB, Gold AL, Shin LM, Lasko NB, Zeidan MA, Handwerger K, Orr SP, Rauch SL (2009) Neurobiological basis of failure to recall extinction memory in posttraumatic stress disorder. Biol Psychiatry 66:1075-1082. CrossRef Medline

Miller NE (1948) Studies of fear as an acquirable drive fear as motivation and fear-reduction as reinforcement in the learning of new responses. J Exp Psychol 38:89-101. CrossRef Medline

Mogenson GJ, Jones DL, Yim CY (1980) From motivation to action: functional interface between the limbic system and the motor system. Prog Neurobiol 14:69-97. CrossRef Medline

Moscarello JM, LeDoux JE (2013) Active avoidance learning requires prefrontal suppression of amygdala-mediated defensive reactions. J Neurosci 33:3815-3823. CrossRef Medline

Mowrer OH (1960) Learning theory and behavior. New York: Wiley.

Mowrer OH, Lamoreaux RR (1946) Fear as an intervening variable in avoidance conditioning. J Comp Psychol 39:29-50. CrossRef Medline

Mueller D, Bravo-Rivera C, Quirk GJ (2010) Infralimbic D2 receptors are necessary for fear extinction and extinction-related tone responses. Biol Psychiatry 68:1055-1060. CrossRef Medline

Muller J, Corodimas KP, Fridel Z, LeDoux JE (1997) Functional inactivation of the lateral and basal nuclei of the amygdala by muscimol infusion prevents fear conditioning to an explicit conditioned stimulus and to contextual stimuli. Behav Neurosci 111:683-691. CrossRef Medline

Nili U, Goldberg H, Weizman A, Dudai Y (2010) Fear thou not: activity of frontal and temporal circuits in moments of real-life courage. Neuron 66:949-962. CrossRef Medline

Pang KC, Jiao X, Sinha S, Beck KD, Servatius RJ (2011) Damage of GABAergic neurons in the medial septum impairs spatial working memory and extinction of active avoidance: effects on proactive interference. Hippocampus 21:835-846. CrossRef Medline

Paxinos G, Watson C (1998). The Rat Brain in Stereotaxic Coordinates. Academic Press: San Diego.

Pelletier JG, Likhtik E, Filali M, Paré D (2005) Lasting increases in basolateral amygdala activity after emotional arousal: implications for facilitated consolidation of emotional memories. Learn Mem 12:96-102. CrossRef Medline

Peters J, De Vries TJ (2013) D-cycloserine administered directly to infralimbic medial prefrontal cortex enhances extinction memory in sucroseseeking animals. Neuroscience 230:24-30. CrossRef Medline

Peters J, LaLumiere RT, Kalivas PW (2008) Infralimbic prefrontal cortex is responsible for inhibiting cocaine seeking in extinguished rats. J Neurosci 28:6046-6053. CrossRef Medline

Peters J, Dieppa-Perea LM, Melendez LM, Quirk GJ (2010) Induction of fear extinction with hippocampal-infralimbic BDNF. Science 328:12881290. CrossRef Medline

Ponnusamy R, Poulos AM, Fanselow MS (2007) Amygdala-dependent and amygdala-independent pathways for contextual fear conditioning. Neuroscience 147:919-927. CrossRef Medline

Poulos AM, Ponnusamy R, Dong HW, Fanselow MS (2010) Compensation in the neural circuitry of fear conditioning awakens learning circuits in the bed nuclei of the stria terminalis. Proc Natl Acad Sci U S A 107:1488114886. CrossRef Medline

Quirk GJ, Repa C, LeDoux JE (1995) Fear conditioning enhances shortlatency auditory responses of lateral amygdala neurons: parallel recordings in the freely behaving rat. Neuron 15:1029-1039. CrossRef Medline

Quirk GJ, Russo GK, Barron JL, Lebron K (2000) The role of ventromedial prefrontal cortex in the recovery of extinguished fear. J Neurosci 20:62256231. Medline

Quirk GJ, Likhtik E, Pelletier JG, Paré D (2003) Stimulation of medial prefrontal cortex decreases the responsiveness of central amygdala output neurons. J Neurosci 23:8800-8807. Medline

Rhodes SE, Killcross S (2004) Lesions of rat infralimbic cortex enhance recovery and reinstatement of an appetitive Pavlovian response. Learn Mem 11:611-616. CrossRef Medline

Rhodes SE, Killcross AS (2007) Lesions of rat infralimbic cortex enhance renewal of extinguished appetitive Pavlovian responding. Eur J Neurosci 25:2498-2503. CrossRef Medline

Santini E, Porter JT (2010) M-type potassium channels modulate the intrinsic excitability of infralimbic neurons and regulate fear expression and extinction. J Neurosci 30:12379-12386. CrossRef Medline

Savonenko A, Filipkowski RK, Werka T, Zielinski K, Kaczmarek L (1999a) Defensive conditioning-related functional heterogeneity among nuclei of the rat amygdala revealed by c-Fos mapping. Neuroscience 94:723-733. CrossRef Medline

Savonenko AV, Brush FR, Zielinski K (1999b) How do rats cope with the two-way escape problem in a homogeneous shuttle box? Acta Neurobiol Exp (Wars) 59:145-157. Medline

Sesack SR, Deutch AY, Roth RH, Bunney BS (1989) Topographical organization of the efferent projections of the medial prefrontal cortex in the rat: an anterograde tract-tracing study with Phaseolus vulgaris leucoagglutinin. J Comp Neurol 290:213-242. CrossRef Medline

Sierra-Mercado D, Padilla-Coreano N, Quirk GJ (2011) Dissociable roles of prelimbic and infralimbic cortices, ventral hippocampus, and basolateral amygdala in the expression and extinction of conditioned fear. Neuropsychopharmacology 36:529-538. CrossRef Medline

Sotres-Bayon F, Quirk GJ (2010) Prefrontal control of fear: more than just extinction. Curr Opin Neurobiol 20:231-235. CrossRef Medline

Sotres-Bayon F, Sierra-Mercado D, Pardilla-Delgado E, Quirk GJ (2012) Gating of fear in prelimbic cortex by hippocampal and amygdala inputs. Neuron 76:804-812. CrossRef Medline

Straube T, Schmidt S, Weiss T, Mentzel HJ, Miltner WH (2009) Dynamic activation of the anterior cingulate cortex during anticipatory anxiety. Neuroimage 44:975-981. CrossRef Medline

Stuber GD, Sparta DR, Stamatakis AM, van Leeuwen WA, Hardjoprajitno JE, Cho S, Tye KM, Kempadoo KA, Zhang F, Deisseroth K, Bonci A (2011) Excitatory transmission from the amygdala to nucleus accumbens facilitates reward seeking. Nature 475:377-380. CrossRef Medline

Theios J, Lynch AD, Lowe WF Jr (1966) Differential effects of shock intensity on one-way and shuttle avoidance conditioning. J Exp Psychol 72: 294-299. CrossRef Medline

Theios JD, Dunaway JE (1964) One-way vs. shuttle avoidance conditioning. Psychonom Sci 1:251-252. CrossRef

Thompson BM, Baratta MV, Biedenkapp JC, Rudy JW, Watkins LR, Maier SF (2010) Activation of the infralimbic cortex in a fear context enhances extinction learning. Learn Mem 17:591-599. CrossRef Medline

Vazdarjanova A, Cahill L, McGaugh JL (2001) Disrupting basolateral amygdala function impairs unconditioned freezing and avoidance in rats. Eur J Neurosci 14:709-718. CrossRef Medline

Vertes RP (2004) Differential projections of the infralimbic and prelimbic cortex in the rat. Synapse 51:32-58. CrossRef Medline

Vidal-Gonzalez I, Vidal-Gonzalez B, Rauch SL, Quirk GJ (2006) Microstimulation reveals opposing influences of prelimbic and infralimbic cortex on the expression of conditioned fear. Learn Mem 13:728-733. CrossRef Medline

Wahlsten D, Sharp D (1969) Improvement of shuttle avoidance by handling during the intertrial interval. J Comp Physiol Psychol 67:252-259. CrossRef Medline

Wendler E, Gaspar JC, Ferreira TL, Barbiero JK, Andreatini R, Vital MA, Blaha CD, Winn P, Da Cunha C (2014) The roles of the nucleus accumbens core, dorsomedial striatum, and dorsolateral striatum in learning: performance and extinction of Pavlovian fear-conditioned responses and instrumental avoidance responses. Neurobiol Learn Mem 109:27-36. CrossRef Medline

Zelikowsky M, Bissiere S, Hast TA, Bennett RZ, Abdipranoto A, Vissel B, Fanselow MS (2013) Prefrontal microcircuit underlies contextual learning after hippocampal loss. Proc Natl Acad Sci U S A 110:9938-9943. CrossRef Medline 